\title{
The Remote Laboratory as a Teaching Resource in the Scientific and Technological Training
}

\author{
Sonia B. Concari ${ }^{1,2}$, Susana T. Marchisio ${ }^{2}$ \\ ${ }^{1}$ Facultad Regional Rosario, Universidad Tecnológica Nacional, Rosario, Argentina \\ ${ }^{2}$ Facultad de Ciencias Exactas, Ingeniería y Agrimensura, Universidad Nacional de Rosario, Rosario, Argentina \\ Email: sconcari@gmail.com
}

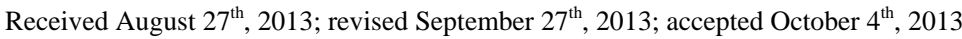

Copyright (C 2013 Sonia B. Concari, Susana T. Marchisio. This is an open access article distributed under the Creative Commons Attribution License, which permits unrestricted use, distribution, and reproduction in any medium, provided the original work is properly cited.

\begin{abstract}
The advances obtained in the field of knowledge of the information and communication technologies (ICT), transformed into a wide range of applications, methods and techniques, have forwarded the development of distance learning through the Internet. When distance learning is linked to disciplines such as Physics, Chemistry and Engineering, the best-known learning management systems (LMS) make it possible to develop some practical activities but these turn out narrow when it is necessary to encourage learning processes through experimental activities. During the last decades, and mostly in the countries in the north hemisphere, this need found a way for the exploration of possibilities, in the development of the remote laboratories. The challenge is that the inclusion of these laboratories in the curriculum is done within the frame of strategies that add value to the teaching processes, giving real chances for the building of learning experiences. This work aims at sharing the findings and thoughts arisen from the analysis of some significant number of experiences carried out by the authors, from the inclusion of the remote laboratory as a complementary teaching resource in different educational environments: courses of Physics for the teaching of Engineering at National Universities, postgraduate training and teaching training.
\end{abstract}

Keywords: Remote Laboratory; Scientific Training; Teaching Resources

\section{Introduction}

The advances in the field of knowledge of the information and communication technologies (ICT), many of which transferred to contexts of use as a wide range of applications, methods and techniques, have become great allies in the development of distance education through the Internet. Several devices and web environments facilitate, among others, the information management, the availability and distribution of multimedia materials, the collaborative development of learning activities, the customization of learning strategies, and the twoway and multi-way communication (synchronous and asynchronous), irrespective of the place. Without being exclusionary, in the field of formal education, the most widespread are the learning management systems (LMS) or platforms, whichalthough becoming stronger and stronger by the emerging social communication tools-are limited when supplying distance education in the field of experimental disciplines. We agree with García Zubia et al. (2009) that it is true that it is possible to carry out some practical activities through the use of those systems (exercises, exams, on-line delivery of projects, etc.); however it is also true that purely practical activities belonging to experimental or technical branches such as Chemistry, Physics or Engineering, cannot find a complete solution within those systems. In these disciplines, the classroom has always been full of resources, tools, different kinds of technologies and has had different teaching aims. Some of them, are used as a support for the representation of messages in different formats, others are within the contexts of laboratories or practice classrooms, whether in academic or professional environments, for the acquisition of skills and abilities as forwarding bridges for the building of knowledge, for scientific training, of design or innovation, for the development of professional skills, among others. The need to keep the development of laboratory practices (which imply interaction with teams, materials and phenomena in real situations) has become in those cases the additional conditioner for the institutions when designing and carrying out—without quality loss-remote teaching offers.

During the last decades, and mostly in the countries in the north hemisphere, this need has found a way for the exploration of possibilities, in the development of the remote laboratories.

\section{Remote Laboratories}

Remote labs are systems that comprise real devices, materials and instruments, organized for the fulfillment of experiments controlled by a remote operator. That way, apart from the real laboratories and the virtual ones based on simulations, remote laboratories are being used in the teaching of Engineering (Auer, 2001), in general, shared by several institutions (Grober, 2008).

Both, ordinary and remote labs require space and devices; all the equipment required to perform the experiment is physically set up. But in remote labs the students who perform the experiment are not physically present in the lab; they obtain data by controlling geographically distant equipment. 
For our point of view, ordinary (hands-on) laboratories involve a physically real investigation process; provide the students with real data and confrontation with contingency, while remote lab allows new ways of experimentation and, in educational terms, it focuses on conceptual understanding. Student's attention is focused mainly on the analysis of results that come from a real experimentation. These labs can extend the capability of a conventional laboratory and increases the number of times and places a student can perform the experiments.

It is not always clear that its use is sustained on a framework of strategies to promote learning building processes (Concari et al., 2012). Regarding this, several authors have highlighted as advantages from these laboratories: the possibility of free experiencing on real devices without being physically present in a laboratory; the flexi time to fulfill practices; the saving of time in tasks done in the traditional laboratory; the safety and confidence at experiencing on expensive equipment (Ibarra et al., 2007). Other benefits highlighted in the bibliography are: the improvement in the availability of laboratory equipment; the increase of laboratory practices; flexi time for experimenting (Saire et al., 2008); the possibility to carry out experiments in a more open way in which students develop skills to solve problems, watch, understand and analyse the outcomes the same way researchers do (Knight, 2003). From our point of view, the challenge is that while existing developments are being spread and experimented in different educational contexts, the inclusion of these laboratories in the curriculum should be framed within proposals that add value to teaching, giving real learning opportunities. In connection with this, the present work aims at sharing the main findings and thoughts arising from the analysis of educational experiences carried out by the authors in the scientific and technological educational environment, regarding the use of two remote laboratories developed in our country.

\section{About Two Remote Laboratories Developed in Argentina}

In our country, the development and use of remote laboratories have been disseminated over the last years; some authors (Lerro \& Protano, 2007; Monje et al., 2009; López Luro et al., 2009; Masanet et al., 2011), who describe the developments belonging to Universidad Nacional de Rosario (UNR), Universidad Nacional del Litoral (UNL), Universidad Nacional de San Juan (UNSJ) and Universidad Nacional de Comahue (UNCo) can be mentioned. At UNR and UNL, the laboratories have started within the framework of projects, whether as the ending of career (Lerro \& Protano, 2007), of research (Monje et al., 2009) or aiming at being transferred to the productive environment (Saéz de Arregui et al., 2013). Furthermore, the latter have been used in the fieldwork of doctoral thesis (San Cristóbal, 2010; Orduña, 2013) and masters degrees (Culzoni, 2013) and they have an important amount of students' and teachers' experiences of use in different educational contexts, in Argentina and abroad, involving classroom-based and remote teaching, engineering graduate and postgraduate, teachers' training at different levels and teaching training advanced students. Staying at UNL, the "Galilei Group Remote Laboratory" is used at teachers' training institutions and at Universidad Nacional de Formosa, Universidad Nacional de Rio Cuarto, Universidad Tecnológica Nacional, at Facultad Regional Rosario and Facultad Regional Rafaela, whereas from UNR, the "FCEIA-UNR Remote laboratory" is also being experimented by Universidad de Deusto, in Spain.

\section{The Galilei Group Remote Laboratory}

The web site for this Remote Laboratory is http://galileo4.unl. edu.ar/.

The software used to access remotely is in applet Java format. In order to be able to execute it, it is necessary to install the plug-in JRE (Java Runtime Environment).

The laboratory provides three experiments. Nowadays we aim at improving the interactivity of the user's interfaces and at achieving more strength in two of the systems containing mobile parts.

The experiments include topics about roto-translation mechanics, transient and state electrical circuits and magnetostatic.

Figure 1 shows the access to the remote laboratory of Galileo Group.

\section{Study of the Roto-Translation Motion of a Wheel in Sloping Railways}

A wheel is a mechanical device with an important moment of inertia used to store rotating energy. The equipment measures the duration of all the movement along the railway. Acceleration (considered steady) is calculated from the data obtained. The system consists of a pair of parallel rails pivoted at a point near the centre that allows for the motion of rails in a vertical direction from one extreme, in order to select the inclination angle. The whole of it is connected to an acquisition board that digitalizes the information: position and time obtained during motion. While the wheel is rotating and moving along the rails, the corresponding values for position and time are observed in a diagram. It allows the user to select, as a parameter, the inclination angle, thus obtaining the results in a diagram and in numbers. The diagrams obtained can be stored in a jpg format, whereas data can be exported to be later processed with mathematical software to facilitate further analysis. It is possible to see the experience live by using an IP camera that supplies images (http://galileo4.unl.edu.ar/descripcionVolante.html).

\section{RC Electric Circuits and RLC Transients}

This experience is aimed at exploring the behavior of RC electric circuits in charge and discharge, RL in charge and RLC in charge and discharge

(http://galileo4.unl.edu.ar/descripcionRLC.html).

It is about the first development of this Remote Laboratory; it is also the one that practically works non-stop and without problems. The physical system is made up of an approximately $6 \mathrm{~V}$ battery, an inductor, a set of capacitors and one set of resistors. All the elements can be connected or disconnected through electromagnetic keys (relays) which are electronically operated. In turn, the system as a whole is controlled from the Internet server, so the remote user can set the circuit, fulfill the experiences and obtain the data about them through diagrams and values charts. The data acquisition interface (A/D board) does measurements every $2 \mathrm{kHz}$. The data from the experiments can be recorded in a text file and then can be processed with some mathematical software or just with a spreadsheet. The following experiments can be set up: charge and discharge of a capacitor through a resistor, RL electric circuit, and RLC electric circuit in charge and discharge. In these latter events it is possible to observe and to study the electromagnetic oscillations, 


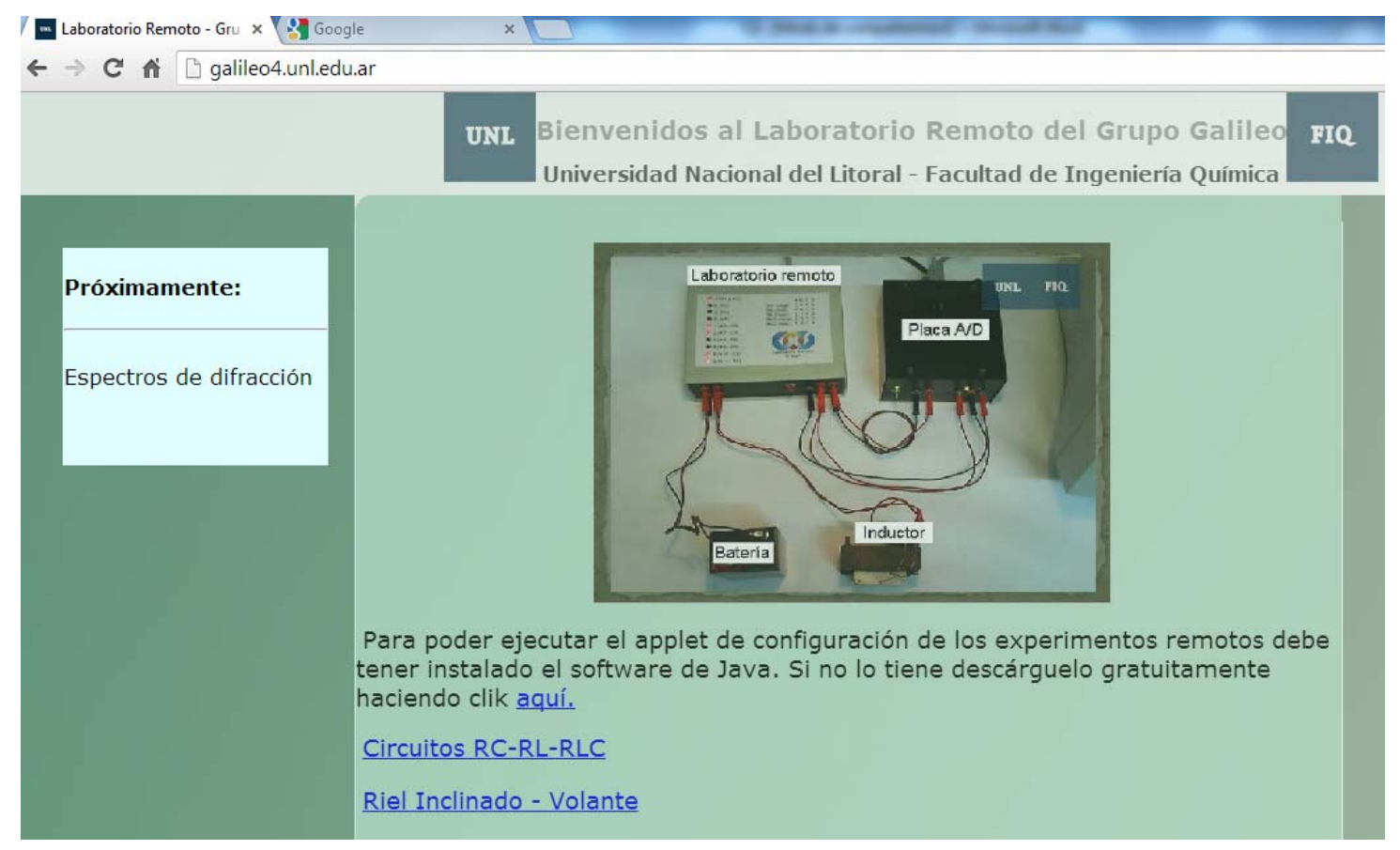

Figure 1.

Web page of the remote laboratory of Galileo Group.

analysing the differences between the ideal model and the experiment, mainly because the inductor has a rolled iron nucleus and the effects of material hysteresis and eddy currents are presented.

\section{Magnetic Field of a Solenoid}

The physical system consists of a great solenoid $(60 \mathrm{~cm}$ of length and $16 \mathrm{~cm}$ of diameter and with 2052 spires), whose dimensions do not fit to the "ideal" type and a couple of Hall effect sensors placed at $90^{\circ}$ from each other, with which two components of the magnetic field can be measured (http://galileo4.unl.edu.ar/descripcionLCM.html).

The measuring point can be moved to different positions, both inside or outside the solenoid, being it possible to manipulate the system through the Internet as a remote experiment. Field values can be measured in independent places as well as collection of data can be obtained along the lines parallel to the axis of the solenoid or in a radial direction. The system includes a simulation of the system, with which it is possible to calculate the field at different points through the Biot and Savart law and to modify the different parameters of the solenoid, thus being possible to approach an ideal device. The remote experiment, linked to the simulation, can be used to study the magnetic field of a solenoid, by comparing the values obtained through experimentation, to the ones that can be calculated using the Ampere and the Biot and Savart laws. It is possible to analyze the convergent of the magnetic field values, calculated with both laws, as the solenoid tends to ideal.

\section{Remote Laboratory FCEIA-UNR}

This laboratory consists of the "Electronic Physics Remote Laboratory" and the "Mobile-remote laboratory for the surveillance of thermal solar energy efficiency".

\section{Remote Laboratory of Electronic Physics}

The straight access to the Electronic Physics Remote Laboratory is http://labremf4a.fceia.unr.edu.ar/; no plug-in or additional applications are necessary on the web browser. This feature makes it strong as regards access possibilities; from any computer with a few requirements in a cyber café, the student can connect and do the experiences, by using a personalized user's name and password. Nowadays it is possible to rehearse remotely: 1) PN junction diode in forward bias; 2) PN junction diode under reverse bias, 3) Zener diode under one-step forward and reverse bias; 4) germanium bipolar transistor in active and reverse modes; 5) silicon bipolar transistor in active and reverse modes; 6) one one-junction transistor; 7) field effect transistors; 8) phototransistor; 9) infrared led.

Remote operation mode with the system is very easy. In the main menu, if you select "new test", the user can choose the device and the test conditions through a drop-down menu. In the operation window, for every experiment there is a scheme of the circuit concerned and the technical specifications sheet of the device. Depending on the interest or the convenience for the required analysis, it is possible to request the following: tests at different temperatures, tests on isolated points, curve sections or complete curves. Results are shown as graphics and charts. During the fulfillment of the experiment, the events are kept in the laboratory database server so the user can recover the information, see the results of the experiment at any time and export data as xls file and the graphic as a gif image. It is possible to modify the graphic scale on the results screen in order to improve the visualization of eventual peculiarities of the resulting curve thus allowing for better analysis.

This laboratory is also integrated into an "e-educativa” platform (Lerro et al., 2013), and it can be accessed without additional validation from the virtual classroom itself. Students have the other teaching materials in that classroom, as simula- 
tions (applets), hypermedia system (Marchisio et al., 2004, 2006) and written materials. They carry out the communicative exchanges (in forums, messages, chat, etc.) for the collaborative building and they hand in the activities. In the subject Physics IV which is part of the career of Electronic Engineering at UNR its use is also articulated with the experimental activities in the laboratory of traditional practices, for the teaching of the main properties of basic electronic devices.

By selecting the curricular experimental activities and by adjusting the instructions related to them according to the desired educational aims, this laboratory has been used, besides, within the framework of teaching training courses at different levels, in subjects in postgraduate careers and in refreshment courses dealing with the inclusion of ICT in higher technological education. Besides, it has been affiliated since 2013 to the WebLab-Deusto (Orduña et al., 2013), as can be seen at Figure 2. The latter is, in turn, affiliated to the MIT remote iLab laboratory, thus allowing students and teachers from the universities concerned to have access from their own Laboratory systems to the experiments that they wish to share from among the ones developed at each institution.

\section{Mobile Remote Laboratory for the in-Situ Measuring of Energy Efficiency of Solar Water Heaters}

In our country, mainly in rural areas, there are solar water heaters in general aimed at supplying the complementary renewable thermal energy to the traditional one in homes. These water heaters need frequent monitoring; particularly, it is important to control their energy efficiency after some time. To do this, it is normally required to take them out of use and carry them to a centre that measures the required parameters under experimental conditions. In order to measure the same parameters in the same solar water heaters, but now under working conditions, in the same place where they are installed, the socalled "mobile remote laboratory" was designed and developed with transfer but also educational aims. It consists of: a mobile device interacting with the solar water heater under study and its surrounding environment. The device collects information, processes it and transmits the interesting values of physical volume via Internet and/or a mobile phone network to a different fixed device placed in the building of Exact Sciences, Engineering and Land Surveys College (Facultad de Ciencias Exactas, Ingeniería y Agrimensura-FCEIA). This device receives the data from the field to be later processed and analysed (Saez de Arregui et al., 2013).

The development was carried out within the framework of the Postgraduate practical training activities inside the institutional space of the Renewable Energies Laboratory of the Master Degree in Energies for Sustainable Development. It is an interdisciplinary team and its members are researchers and students of the career and from the Remote Tests Laboratory of the FCEIA. This articulation has helped to optimize resources and to boost learning and services. Apart from becoming a teaching resource for several subjects in the career, its design and development have been carried out by postgraduate students as a project including the training itself, the innovation and its transfer to society as goals. Thus, as products of the project called "Thermal solar energy mobile remote laboratory. Innovation technology for tests/solutions leading to energy saving", the devices developed are available in order to analyse the behavior of solar water heaters in different regions under different climatic situations solving the problems mentioned before. The project was preselected in the 2012 INNOVAR contest and the mobile remote laboratory was shown in TECNÓPOLIS (http://galeria.innovar.gob.ar/13497).

\section{Possibilities and Educational Difficulties}

Once the technological problem is settled, the main questions arise from a teaching nature: How can the remote laboratory be included into the teaching in different contexts? Which teaching strategies shall include it? Is it necessary to have certain conditions for the remote laboratory to become a teaching resource? Which condition? How shall learning be tested? These questions have given birth to teaching experiences developed in the different training contexts in order to test them under situations of use, where over two thousand users among students and teachers took part.

In this regard, in no case have these laboratories substituted the experimental activities in the traditional laboratory. With the aim of giving students different significant and convergent forms of knowledge building, the activities suggested to students by using the remote laboratory were designed to promote the development of those cognitive strategies known as useful in the environment of experimental sciences and engineering teaching and integrated to other teaching resources. These are framed within problem-solving and design activities that demand for search and contrast of experimental information, the building of hypothesis of control variables, the development of synthesis and integration with theoretical knowledge, the comparison and building of models (Lerro et al., 2012; Kofman \& Concari, 2012) and the collaborative production of knowledge from the integration of hypermedia environments (Lerro et al., 2013).

\section{The Achievements}

The results for uses in such contexts report that the technical and teaching requirements have been adapted to the suggested learning aims; that the experiments that have a web cam could be visualized with very good resolution; that students could carry out the experiments, obtain and process data and do the required calculations, in a collaborative way and engaged with the task assigned, to test the resource and to suggest interesting improvements in the design, getting involved and engaged with the task. Learning experiences in the environment of graduate university degree have been evaluated through the solving of new problems at formal academic testing-term and mid-term exams-showing significant learning (Kofman et al., 2011; Marchisio et al., 2010).

On the other hand, using remote laboratories with engineering students helped them to get in touch with technologies and methodologies connected to remote measuring that they shall use as future professionals. All this happens simultaneously in situations in which the collective takes place as a production space, along a process that compromises ways of approaching and developing technologies such as occurs in the professional environments today. All this has been deeply valued by university degree (Concari et al., 2012) and postgraduate (Saez de Arregui et al., 2012) students.

In the field of teaching training, teachers from Escuela Industrial Superior and from UNL in Santa Fe, and teachers from the Instituto Politécnico Superior from UNR, and from UTN, in 

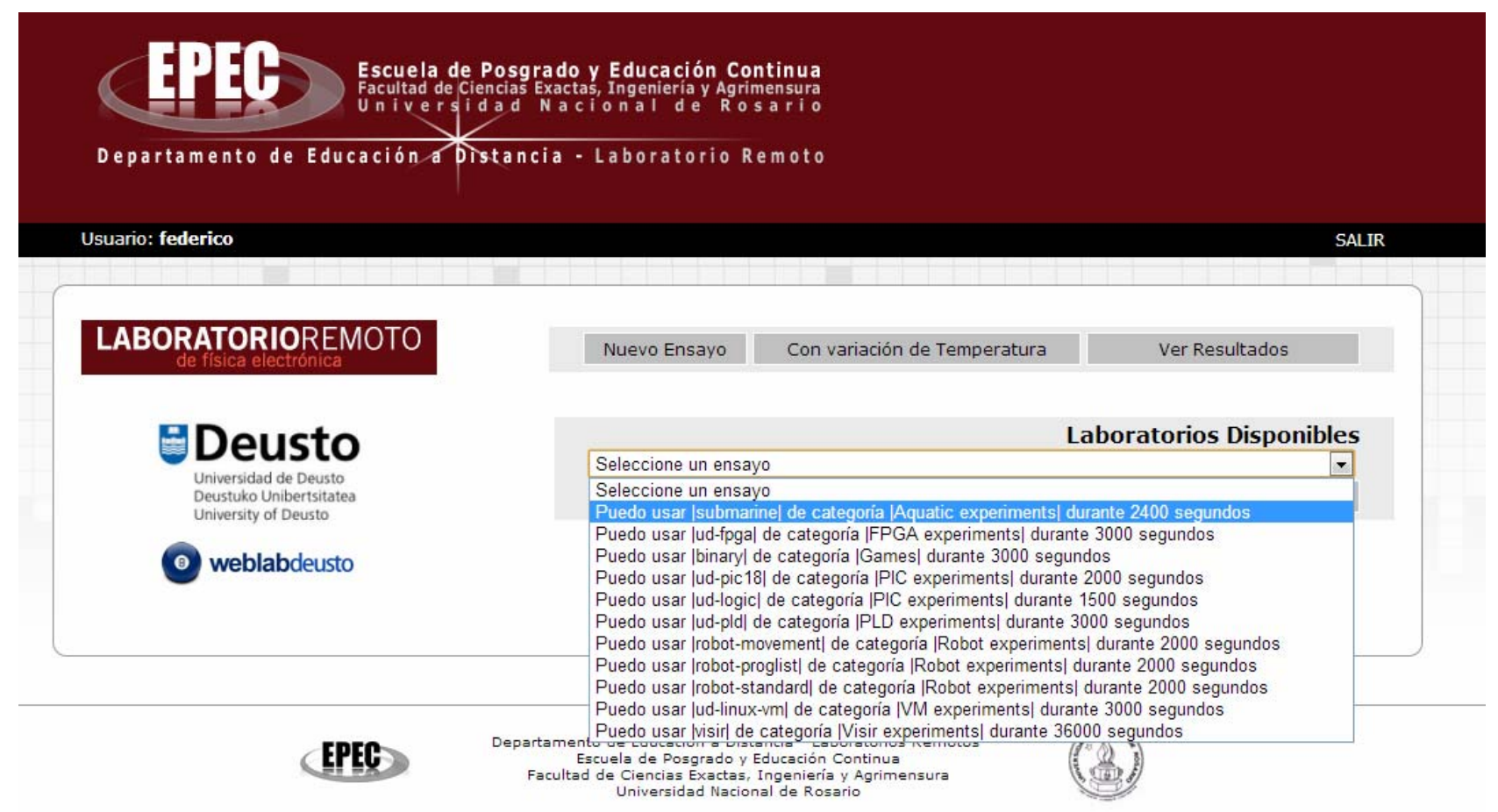

Figure 2.

Remote labs from WebLab-Deusto at UNR.

Rosario have been trained through face-to-face workshops. Teachers from Universidad Nacional de Cuyo, from teacher training institutions in the south of Mendoza state and from high schools from Santa Fe, Entre Ríos, Corrientes and Misiones, got in touch with these remote laboratories through a remote learning course within the framework of teaching strategies that include the use of ICT in Physics problem-solving activities in an integrated way. The design of courses and workshops included activities integrating disciplinary contents and teaching methodologies. The training instances offered spaces for collective thoughts, scarce in high schools in Argentina. Inquiry and critical thoughts processes were encouraged; these make it possible to question and build teaching styles coherent with different kinds of knowledge and educational contexts. The thought arising from the analysis of this amount of experiences allows us to say that these remote laboratories are not just suitable resources in order to make it easier for students to access the experimenting at any place and time. These can also become media for the encouragement of individual constructive processes of significant scientific learning that simplify the joint action (Coll, 2004) among students and teachers, both in a web environment and in face-to-face instances, improving dictations in the "suitable curricular moment”, including experimental observation into the context of theoretical construction. From the point of view of the analysis of educational results, the evaluation carried out by students allows us to value the experience as highly positive. When asking about their opinions on the use of this resource in the framework of active learning strategies (Marchisio et al., 2010) students have not only shown their satisfaction and done interesting assessments as suggestions for improvements; they have also accounted for their involvement in decision-making over their own learning process.
From the point of view of interdisciplinary teams involved in the development, design and use of these resources, we should highlight how remote experimenting with testing and research aims in connection with the educational possibilities of the resource have created opportunities for the setting up of research and teaching collaborative networks with participation of Argentine and foreign universities. However, not all has turned out positive. From the tests fulfilled the existence of some constraints has also occurred. Among difficulties or problems to overcome there are some issues of a technical nature, intrinsic to the experiment; other technical ones but associated to the technological management in institutions and, finally, some drawbacks associated to acceptance (or non acceptance) by teachers. As regards problems, the following are highlighted:

Execution time for mechanical experiments is quite long. Beyond time normally required due to the nature of the experiment, when there are several students trying to access the experiment at the same time, the system makes them hold on. It causes impatience and some people leave or delay the activity.

Slowness and instability of some Internet academic networks and institutional use of protection systems that jam certain not normally used ports but that must be necessarily accessible in remote experiments.

Not all teachers having access to the remote laboratory as a resource have included it in teaching contexts. As all brand new technology, it is not immediately included in the classroom environment. It is a process that demands for higher knowledge and experimentation by the teacher; the analysis and visualization of its potential use; curricular thought; exchange of ideas with partners in the classroom environment; changes in the ordinary teaching methods, among other actions. 


\section{Conclusion and Future Work}

Remote labs open the doors to the university labs so that students can go into them and perform different experiences on subjects based on Physics both for engineering and sciences teaching.

Future work will follow two directions. Technological development has to be done to adapt access to remote labs from smart phones, so students could do the experiments using these dispositives from any place where there is an Internet connection.

Also other next working stage will be centered on the investigation of the evaluation criteria from a didactic point of view of the remote labs applying them to get information that will allow us to optimize its use for educational purposes.

\section{Acknowledgements}

This work has been realized by grants of Universidad Tecnológica Nacional and Universidad Nacional de Rosario Rosario in the frame of projects: UTN-25/M064, UNR-1ING374 and UNR-1ING396.

\section{REFERENCES}

Auer, M. E. (2001). Virtual lab versus remote lab. 20th World Conference on Open Learning and distance Education, Dusseldorf, April 2001.

Barco, H., Arango, P., \& Restrepo, E. (2009). Laboratorios remotos de física general. Una alternativa para la enseñanza.

http://www.istec.org/wp-content/gallery/ebooks/ace/docs/ace-semina r09-final8.pdf

Coll, C. (2004). Psicología de la educación y prácticas educativas mediadas por las TIC. Sinéctica, 25, 1-24. http://www.ub.edu/grintie

Concari, S., Kofman, H., \& Marchisio, S. (2012). Laboratorios remotos y educación en Ingeniería. Entre retos y posibilidades. XVII Congreso Internacional de Tecnologías para la Educación y el Conocimiento: Tecnologías Emergentes. UNED. España.

Culzoni, C. (2013). Calidad de las interacciones en una propuesta para enseñanza de la física en aula virtual y utilizando un Laboratorio Remoto. Revista VESC, 6, 29-43.

http://revistas.unc.edu.ar/index.php/vesc/article/view/4645

Garcia-Zubia, J., Hernandez, U., Angulo, I., Orduña, P., \& Irurzun, J. (2009). Acceptance, usability and usefulness of weblab-deusto from the students point of view. International Journal of Online Engineering, 5. http://dx.doi.org/10.3991/ijoe.v5i1.817

Gravier, C., Fayolle, J., Bayard, B., Ates, M., \& Lardon. J. (2008). State of the art about remote laboratories paradigms-Foundations of ongoing mutations. International Journal of Online Engineering, 4, 1925.

Gröber, S., Vetter, M., Eckert, B., \& Jodl, H.-J. (2008) Remotely controlled laboratories: Aims, examples, and experience. American Journal of Physics, 76, 374. http://dx.doi.org/10.1119/1.2885058

Grupo Galileo (2008). Laboratorio remoto del grupo galileo. Facultad de Ingeniería Química. Universidad Nacional del Litoral. http://www.fiq.unl.edu.ar/galileo/

Ibarra, C., Medina S., \& Bernal, Á. (2007). Implementación de un laboratorio virtual para el estudio de dispositivos electrónicos. TeyET, 2, 62-70.

Juarez Bento da Silva (2009). Utilização de experimentação remota como suporte a ambientes de ensino-aprendisagem na rede publica de ensino. FRIDA 2009.

https://repositorio.ufsc.br/bitstream/handle/123456789/88357/24194 9.pdf?sequence $=1$

Knight, M. (2003). Connecting and teaching students via web services for an online laboratory. Doctoral Dissertation, Massachusetts Institute of Technology.

Kofman, H., \& Concari, S. (2012). Using remote lab for physics teach- ing. In J. García Zubía, \& G. Alves (comp.), Using remote labs in education (pp. 293-308). Universidad de Deusto.

http://www.deusto-publicaciones.es/index.php/main/libro/913

Kofman, H., Pérez Sottile, R., Concari, S., \& Sarges Guerra, A. (2011). Experiments in rigid body mechanics using a remote laboratory. Proceedings of INTED2011 Conference, CD. IATED Publication.

Lerro, F., \& Protano, M. (2007). Web-based remote semiconductors devices testing laboratory. International Journal of Online Engineering, 3, 1-4.

Lerro, F., Marchisio, S., Martini, S., Massacesi, H., Perretta, E., Gimenez, A., Aimetti, N., \& Oshiro, J. (2013). Realización a distancia de experimentos reales desde un sistema de gestión de aprendizajes. Revista VAEP-RITA, 1.

http://rita.det.uvigo.es/VAEPRITA/index.php?content=Num_Pub\&id iom=Es\&visualiza $=1 \&$ volumen $=1$ \&numero $=2 \&$ orden $=$ desc

Lerro, F., Marchisio, S., Perretta, E., Plano, M., \& Protano, M. (2012). Using the remote lab of electronics physics ("laboratorio remoto de física electrónica”) to support teaching and learning. In: J. García Zubía, \& Alves, G. (comp.), Using remote labs in education (p. 211-230). Universidad de Deusto. http://www.deusto-publicaciones.es/index.php/main/libro/913

Lloret, J., Jimenez, J. M., Diaz, J. R., \& Lloret, G. (2008). A remote network laboratory to improve university classes. Proceedings of the 5th WSEAS/IASME international conference on Engineering Education (EE'08), Greece.

López Luro, F., Bertogna, L., Sánchez, L., Rodríguez, J., \& Del Castillo, J. (2009). Infraestructura para laboratorios de acceso remoto. Revista TE\&ET, 31-39.

http://teyet-revista.info.unlp.edu.ar/nuevo/files/No4/TEYET4-art04.p df

Marchisio, M., Plano, M., Ronco, J., \& Von Pamel, O. (2004). Introducing hypermedia learning resources in a Physics course on semiconductor devices for electronic engineering students. International Conference on Engineering Education and Research. Technical University of Ostrava, Czech Republic.

Marchisio, M., Plano, M., Ronco, J., \& Von Pamel, O. (2006). Experiencia con uso de simulaciones en la enseñanza de la física de los dispositivos electrónicos, Revista Cognición, 2. http://www.cognicion.net/

Marchisio, S., Lerro, F., \& Von Pamel, O. (2010). Use of a remote laboratory to promote meaningful learning in the teaching of electronic devices. Pixel-Bit. Revista de Medios y Educación, 129-139. http://www.sav.us.es/pixelbit/actual/10.pdf

Masanet, M., Zavalla, E., \& Fernández, A. (2011). Un enfoque integrado para las prácticas de laboratorio en la educación a distancia. Revista TE\&ET, 65-70.

http://teyet-revista.info.unlp.edu.ar/nuevo/files/No6/TEYET6-art09.p $\mathrm{df}$

Monje, R., Kofman, H., Lucero, P., \& Culzoni, C. (2009). Experimentos remotos de circuitos eléctricos con fenómenos transitorios. Revista Iberoamericana de Informática Educativa, 9. http://161.67.140.29/iecom/index.php/IECom/issue/current

Orduña, P. (2013). Transitive and scalable federation model for remote laboratories. PhD Thesis, Universidad de Deusto. http://www.weblab.deusto.es/pub/dissertation_pablo.pdf

Orduña, P., Lerro, F., Bailey, P., Marchisio, S., DeLong, K., Perreta, E., Dziabenko, O., Angulo, I., López-de-Ipiña, D., \& Garcia-Zubia, J. (2013). Exploring complex remote laboratory ecosystems through interoperable federation chains. 4th IEEE Global Engineering Education Conference (EDUCON), Berlin, March 2013.

http://www.weblab.deusto.es/web/images/publications/educon2013_i nterop.pdf http://dx.doi.org/10.1109/EduCon.2013.6530259

Saez de Arregui, G., Plano, M., Lerro, F., Petrocelli, L., Marchisio, S., Concari, S., \& Scotta, V. (2012). Un sistema laboratorio remoto móvil para la educación en el área de energías para el desarrollo sostenible. WEEF, Buenos Aires.

Saez de Arregui, G., Plano, M., Lerro, F., Petrocelli, L., Marchisio, S., Concari, S., \& Scotta, V. (2013). A mobile remote lab system to monitor in situ thermal solar installations. International Journal of Interactive Mobile Technologies, 7, 31-34. 


\section{S. B. CONCARI, S. T. MARCHISIO}

http://www.online-journals.org/index.php/i-jim

Saire, A., \& Gómez, H. (2008). Distance learning environment in industrial automation using remotes laboratories. Investigación Aplicada e Innovación, 2, 109-116.
San Cristóbal Ruiz, E. (2010). Metodología, estructura y desarrollo de interfaces intermedias para la conexión de laboratorios remotos y virtuales a plataformas educativas. Doctoral Dissertation, Madrid: National University for Distance Education. 